\title{
KETRAMPILAN PIJAT BAYI PADA PRIMIPARA DAN MULTIPARA
}

\section{Etika Purnama Sari ${ }^{1}$}

\begin{abstract}
Primipara has more concern to fulfill baby's needs, one of which is baby massage. Multipara has more experience, but they are also faced with other demands. The behavior of mothers to do baby massage with the right technique is not much done. The purpose of this study is to analyze the skills of baby massage in primipara and multipara. The research design used is comparative analytics with the Cross Sectional approach. The population in this study were primipara and multipara. The sample in this study was 41 people, using a simple random sampling technique. The method of collecting data uses an observation sheet.

The results showed the skills of multiparous baby massage with a good category (81\%) while primipara as much $(60 \%)$ in the bad category. The results of the chi square statistical analysis obtained a value of $p=0.018$ and $\alpha=0.05$ where $p<\alpha$, which means there is a difference between infant massage skills in primiparas and multiparas. Differences in primipara and multipara skills in baby massage techniques due to many factors including information, experience, and level of education. Primipara is expected to have more desire to massage her baby well and multiparas are expected to do baby massage more often.
\end{abstract}

Keywords: baby massage, primipara, multipara

\section{PENDAHULUAN}

Perilaku dapat dikatakan sebagai dorongan kuat bagi seseorang untuk melakukan segala sesuatu dalam mewujudkan pencapaian tujuan dan cita-cita yang menjadi keinginannya. Demikian pula dengan seorang ibu yang mendambakan semua hal yang terbaik untuk masa depan anaknya (Nugroho, 2013).

Bagi para ibu primipara menjadi seorang ibu merupakan peran baru dan sulit. Ibu-ibu primipara umumnya memiliki kepedulian untuk memenuhi kebutuhan bayi, salah satunya pijat bayi. Pada ibu multipara, meskipun mereka sudah memiliki pengalaman, mereka juga dihadapkan pada tuntutan kebutuhan lain. Mereka memiliki sistem dan fungsi keluarga yang lebih kompleks. Salah satu kepedulian ibu multipara selain melakukan pijat bayi adalah mempersiapkan anak-anak mereka menerima kehadiran adik / anggota baru dan persiapan dirinya menjadi ibu bagi bayi yang baru saja dilahirkan dan anak-anak lainnya (Afiyanti, 2007). Begitu besar perilaku ibu untuk melakukan sesuatu diantaranya pijat bayi, namun perilaku ibu untuk melakukan dengan teknik yang benar belum banyak yang melakukan dan belum banyak yang mengetahui tentang pengaruh positif memijat untuk bayi dan ibunya terutama bila dilakukan sendiri oleh ibu (Nugroho, 2013).

Menurut survei pendahuluan yang dilakukan peneliti pada tanggal 2 Desember 2017 di RT 02 RW 01 Kelurahan Kapas Madya Baru Kecamatan Tambaksari didapatkan jumlah keseluruhan ibu primipara 25 orang, dan ibu multipara 41 orang. Dari hasil wawancara 10 orang yang terdiri dari 6 orang ibu multipara dan 4 orang ibu primipara, 4 orang diantaranya mengatakan tidak pernah memijat bayinya sendiri karena takut, sedangkan 3 orang mengatakan bahwa sesekali memijat bayinya secara mandiri dan 3 lainnya memijatkan bayinya ketika 
ibu bayi libur kerja ke dukun bayi. Di RT 02 RW 01 minat dari ibu bayi cukup tinggi tentang pijat bayi namun belum dilakukan secara mandiri.

Adapun faktor - faktor yang mempengaruhi dalam melakukan pijat bayi yang dilakukan oleh ibu, antara lain pendidikan, informasi, media cetak dan media elektronik. Faktor lainnya yang mempengaruhi ibu memijatkan bayinya bisa oleh faktor sikap ibu juga dibentuk oleh faktor dukungan keluarga. Hal ini sesuai dengan pendapat Subakti yang menjelaskan dukungan keluarga yaitu komunikasi verbal maupun non verbal, bantuan, serta saran yang diberikan kepada orang yang terdekat dan dapat memberikan keuntungan emosional yang berpengaruh terhadap tingkah lakunya (Subakti, 2008).

Banyak manfaat dilakukan pijat bayi yang dilakukan oleh orang tua bayi. Sebenarnya, pijat yang dilakukan oleh tenaga nonmedis tidak selalu salah, ada juga tenaga non medis yang menguasai ilmu tentang anatomi tubuh anak. Akan tetapi, mereka tetap terus berhati-hati, mengingat angka kejadian efek samping pijat yang tidak diinginkan cukup banyak, misalnya setelah dipijat anak merasakan sakit di seluruh tubuhnya, anak menjadi sulit buang air kecil, hingga terjadinya ileus (gangguan pergerakan usus, dimana usus berhenti bergerak). Biasanya anak yang mengalami ileus akan menunjukan gejalagejala, seperti tidak dapat buang air besar, perut kembung dan kesakitan (Yahya, 2011).

Sebaiknya pemijatan dilakukan pagi hari sebelum mandi, atau bisa juga malam hari sebelum bayi tidur, karena aktifitas bayi sepanjang hari cukup melelahkan. Pijat bayi dapat dilakukan sejak umur 1 bulan sampai dengan 2 tahun dapat dilakukan sekitar 15 menit. Tindakan pijat dikurangi seiring dengan bertambahnya usia bayi. Sejak usia enam bulan, pijat dua hari sekali sudah memadai. Upaya agar masyarakat mampu merubah perilaku ibu melakukan pijat bayi maka petugas kesehatan perlu melakukan penyuluhan dan survei pada ibu primipara dan multipara.

\section{TUJUAN PENELITIAN}

Secara umum penelitian ini bertujuan untuk menganalisis perbandingan ketrampilan pijat bayi pada ibu primipara dan multipara di RT 02 RW 01 Kelurahan Kapas Madya Baru Kecamatan Tambaksari Surabaya dan tujuan khususnya adalah mengidentifikasi ketrampilan pijat bayi pada ibu primipara, mengidentifikasi ketrampilan pijat bayi pada ibu multipara serta membandingkan ketrampilan pijat bayi pada ibu primipara dan multipara di RT 02 RW 01 Kelurahan Kapas Madya Baru Kecamatan Tambaksari Surabaya.

\section{METODE/DESAIN PENELITIAN}

Desain penelitian yang digunakan adalah analitik komparasi dengan pendekatan Cross Sectional yang dilakukan untuk mencari perbandingan terhadap pengaruh pada kelompok subjek tanpa adanya suatu perlakuan dari peneliti.

Penelitian dilakukan pada 29 Januari - 3 April 2018 di RT 02 RW 01 Kelurahan Kapas Madya Baru Kecamatan Tambaksari Surabaya. Pada penelitian ini membandingkan perilaku pijat bayi pada ibu primipara dan ibu multipara.

\section{POPULASI, SAMPEL DAN TEKNIK SAMPLING}

Populasi yang dimaksud dalam penelitian ini berjumlah 46 ibu primipara dan ibu multipara. Sampel yang dimaksud adalah sejumlah ibu primipara 20 orang dan ibu multipara 21 orang. Teknik sampling yang digunakan dalam penelitian ini 
Simple Random Sampling. Uji statistik yang digunakan untuk mengetahui perbandingan perilaku pijat bayi pada ibu primipara dan multipara adalah dengan menggunakan uji Chi Square. Pengumpulan data menggunakan lembar observasi dengan jumlah pertanyaan 42 pertanyaan yang terdiri dari persiapan 8 pertanyaan dan pelaksanaan 34 pertanyaan.

\section{HASIL PENELITIAN}

Hasil penelitian ini dapat dijabarkan sebagai berikut:

Tabel 1.

Distribusi Usia Responden

\begin{tabular}{ccccc}
\hline Usia & \multicolumn{2}{c}{ Primi } & \multicolumn{2}{c}{ Multi } \\
\cline { 2 - 5 } (thn) & $f$ & $\%$ & $f$ & $\%$ \\
\hline $26-35$ & 20 & 100 & 19 & 91 \\
$36-45$ & 0 & 0 & 2 & 9 \\
\hline Jumlah & 20 & 100 & 21 & 100 \\
\hline
\end{tabular}

Tabel 1 menunjukkan bahwa ibu primipara seluruh respondennya $(100 \%)$ dan ibu multipara hampir seluruhnya $(91 \%)$ berusia $26-35$ tahun.

Tabel 2.

Distribusi Pendidikan Terakhir

\begin{tabular}{ccccc}
\hline \multirow{2}{*}{$\begin{array}{l}\text { Pendidik } \\
\text { an Terak }\end{array}$} & \multicolumn{2}{c}{ Primi } & \multicolumn{2}{c}{ Multi } \\
\cline { 3 - 5 } hir & $\mathrm{f}$ & $\%$ & $\mathrm{f}$ & $\%$ \\
\hline SD & 0 & 0 & 0 & 0 \\
SMP & 0 & 0 & 2 & 10 \\
SMA & 13 & 65 & 12 & 57 \\
PT & 7 & 35 & 7 & 33 \\
\hline Jumlah & 20 & 100 & 21 & 100 \\
\hline
\end{tabular}

Tabel 2menunjukkan bahwa sebagian besar ibu primipara sebagian besar (65\%) mempunyai tingkat pendidikan SMA dan pada ibu multipara sebagian besar (57\%) juga berpendidikan SMA.
Tabel 3.

Distribusi Frekuensi

Pijat Bayi Responden

\begin{tabular}{ccccc}
\hline Frekuensi & \multicolumn{2}{c}{ Primi } & \multicolumn{2}{c}{ Multi } \\
\cline { 2 - 5 } Pijat Bayi & $f$ & $\%$ & $f$ & $\%$ \\
\hline Setiap Hari & 9 & 45 & 0 & 0 \\
1 Minggu & 8 & 40 & 1 & 5 \\
$\begin{array}{c}\text { Sekali } \\
1 \text { Bulan }\end{array}$ & 3 & 15 & 11 & 52 \\
$\begin{array}{c}\text { Sekali } \\
\text { Bila Anak } \\
\text { Sakit Saja }\end{array}$ & 0 & 0 & 7 & 33 \\
\hline Jumlah & 20 & 100 & 21 & 100 \\
\hline
\end{tabular}

Tabel 3 menunjukkan bahwa sebagian besar ibu primipara $(45 \%)$ memijat bayinya setiap hari sedangkan pada ibu multipara sebagian besar (52\%) memijat bayinya 1 bulan sekali.

Tabel 4

Distribusi Perilaku Pijat Bayi Pada Ibu Primipara dan Multipara

\begin{tabular}{ccccc}
\hline Perilaku & \multicolumn{2}{c}{ Primi } & \multicolumn{2}{c}{ Multi } \\
\cline { 2 - 5 } Pijat Bayi & $f$ & $\%$ & $f$ & $\%$ \\
\hline Buruk & 12 & 60 & 4 & 19 \\
Baik & 8 & 40 & 17 & 81 \\
\hline Jumlah & 20 & 100 & 21 & 100 \\
\hline
\end{tabular}

Tabel 4 menunjukkan bahwa perilaku pijat bayi pada ibu primipara sebagian besar $(60 \%)$ buruk sedangkan pada ibu multipara sebagian besar (81\%) baik.

Tabel 5.

Hasil Analisa Statistik Chi Square

\begin{tabular}{cc}
\hline Indikator & Nilai \\
\hline$P$ value (Sig 2-tailed) & 0,018 \\
A & 0,05
\end{tabular}

Berdasarkan tabel 5 Hasil analisa statistik chi square diperoleh nilai $p=0,018$ dan $\alpha=0,05$ dimana $p<\alpha$ yang artinya terdapat perbedaan antara perilaku pijat bayi pada ibu primipara dan multipara. 


\section{PEMBAHASAN}

Berdasarkan Tabel 5, hasil analisa statistik chi square diperoleh nilai $p=0,018$ dan $\alpha=0,05$ dimana $p<\alpha$ yang artinya ada perbedaan antara perilaku pijat bayi pada ibu primipara dan multipara.

Pijat adalah terapi sentuh tertua yang dikenal manusia dan yang paling popular. IImu kesehatan modern telah membuktikan secara ilmiah bahwa terapi sentuhan dan pijat pada bayi mempunyai banyak manfaat (Lestari, 2013). Pijat dapat dilakukan pada usia berapa pun, termasuk bayi (Andriyani, 2015). Pijat bayi yaitu suatu teknik sentuhan yang dapat memberikan manfaat pengobatan (Afriyanti dan Asri, 2014). Dikatakan terapi sentuh karena melalui pijat bayi akan terjadi komunikasi yang nyaman dan aman antara ibu dan buah hatinya (Riksani, 2012). Pijat bayi memberikan manfaat yang besar bagi bayi dan ibu bila dilakukan secara mandiri (Rismundari dan Sri, 2012). Ibu adalah orang tua paling dekat dengan bayi, dimana pijatan ibu kepada bayinya adalah sapuan lembut pengikat jalinan kasih sayang. Kulit ibu adalah kulit yang paling awal dikenali oleh bayi (Aminati, 2013). Faktor yang mempengaruhi dalam melakukan pijat bayi yang dilakukan oleh ibu, antara lain pendidikan, informasi, media cetak dan media elektronik. Faktor lainnya yang mempengaruhi ibu memijatkan bayinya bisa oleh faktor sikap ibu juga dibentuk oleh faktor dukungan keluarga. Hal ini sesuai dengan pendapat Yazid yang menjelaskan dukungan keluarga yaitu komunikasi verbal maupun non verbal, bantuan, serta saran yang diberikan kepada orang yang terdekat dan dapat memberikan keuntungan emosional yang berpengaruh terhadap tingkah lakunya (Subakti, 2008). Bagi para ibu primipara menjadi seorang ibu merupakan peran baru dan sulit.
Ibu-ibu primipara umumnya memiliki kepedulian untuk memenuhi kebutuhan bayi, salah satunya pijat bayi. Pada ibu multipara, meskipun mereka sudah memiliki pengalaman, mereka juga dihadapkan pada tuntutan kebutuhan lain. Mereka memiliki sistem dan fungsi keluarga yang lebih kompleks. Salah satu kepedulian ibu multipara selain melakukan pijat bayi adalah mempersiapkan anak-anak mereka menerima kehadiran adik / anggota baru dan persiapan dirinya menjadi ibu bagi bayi yang baru saja dilahirkan dan anak-anak lainnya (Afiyanti, 2007). Begitu besar perilaku ibu untuk melakukan sesuatu diantaranya pijat bayi, namun perilaku ibu untuk melakukan dengan teknik yang benar belum banyak yang melakukan dan belum banyak yang mengetahui tentang pengaruh positif memijat untuk bayi dan ibunya terutama bila dilakukan sendiri oleh ibu (Nugroho, 2013).

Berdasarkan hasil penelitian dapat dilihat bahwa ada perbandingan antara perilaku pijat bayi pada ibu primipara dan multipara, perilaku pijat bayi pada ibu primipara didapatkan perilaku memijat buruk lebih banyak daripada yang baik, dari hasil wawancara bersama responden dikarenakan faktor informasi yaitu belum ada penyuluhan, faktor pengalaman yang kurang dan faktor belum terbiasa memijat bayinya sehingga kebutuhan memijat bayinya kurang terlaksana dengan baik. Ada sebagian ibu primipara yang berkategori baik, hal ini dikarenakan keinginan atau motivasi ibu lebih besar untuk memijat bayinya secara baik dapat dilihat dari frekuensi dalam memijat bayi.

Perilaku pijat bayi pada ibu multipara didapatkan perilaku memijat baik lebih banyak daripada yang buruk, dari hasil wawancara dengan responden hal ini 
dikarenakan dari faktor pengalaman jumlah anak mereka lebih dari satu, faktor informasi ada beberapa ibu dari hasil wawancara ada yang mencari informasi melalui internet, dan faktor tingkat pendidikan akhir dapat dilihat bahwa ibu yang berperilaku pijat baik sebagian besar tingkat pendidikan SMA dan perguruan tinggi. Ada sebagian ibu multipara yang berkategori buruk, hal ini dikarenakan kesibukan ibu dalam mengurus keluarga yang memiliki anak lebih dari satu dan mengurus rumah tangga dan dari tingkat pendidikan ada yang SMP sehingga akan mempengaruhi perilaku.

\section{KESIMPULAN}

1. Sebagian besar ketrampilan pijat bayi pada ibu primipara di RT 02 RW 01 Kelurahan Kapas Madya Baru Kecamatan Tambaksari Surabaya dalam kategori buruk.

2. Sebagian besar ketrampilan pijat bayi pada ibu multipara di RT 02 RW 01 Kelurahan Kapas Madya Baru Kecamatan Tambaksari Surabaya dalam kategori baik.

3. Ada perbedaan antara ketrampilan pijat bayi pada ibu primipara dan multipara di RT 02 RW 01 Kelurahan Kapas Madya Baru Kecamatan Tambaksari Surabaya.

\section{SARAN}

1. Untuk Tempat Peneliti

a. Diharapkan untuk RT 02 RW 01 Kelurahan Kapas Madya Baru Kecamatan Tambaksari Surabaya mengundang ahli terapi pijat bayi yang baik sehingga bisa menambah wawasan informasi bagi ibu primipara dan multipara.

b. Diharapkan untuk kedepannya di RT 02 RW 01 Kelurahan Kapas Madya Baru Kecamatan Tambaksari
Surabaya ada penyuluhan mengenai pentingnya pijat bayi yang dilakukan oleh orang tua kandung sendiri.

2. Untuk Peneliti Selanjutnya

a. Sebagai tenaga di bidang kesehatan diharapkan untuk peneliti selanjutnya mengembangkan metode penelitian seperti memberikan penyuluhan pijat bayi kepada para ibu primipara dan multipara yang dilakukan orang tua sendiri.
b. Diharapkan peneliti memperluas wilayah penelitian.

3. Para orang tua yang memiliki bayi disarankan lebih intensif dalam melakukan pijat bayi secara mandiri dan mencari wawasan mengenai pijat bayi yang dilakukan oleh orang tua sendiri.

\section{DAFTAR PUSTAKA}

Afiyanti Y, I. N. 2007. Perbedaan Kepedulian Maternal Antara Ibu Primipara dan Ibu Multipara Pada Awal Periode Post Partum. Jurnal Keperawatan Indonesia.

Afriyanti, Rika dan Asri Hidayat. 2014. Pengaruh Demonstrasi terhadap Perilaku lbu dalam Melakukan Pijat Bayi di BPS Dini Melani Condong Catur Sleman Tahun 2014. Skripsi. STIKES 'Aisyiyah Yogyakarta. http://digilib.unisayogya.ac.id/12 23.

Aminati, D. 2013. Pijat dan senam untuk bayi dan balita. Brilliant Books, Yogyakarta.

Andriyani, Rika. 2015."Relationship Of Mother Attitude About Infant Massage With Mother Behavior In Baby Massage At Posyandu Sidomulyo Health Center Area, Pekanbaru". Jurnal Kesehatan Komunitas. Volume 2 No. 2. Diakses dari 
http://jurnal.htp.ac.id/index.php/ keskom/article/view/87.

Heriyanto, Bambang. 2017. Metode Penelitian Kuantitatif. CV Perwira Media Nusantara, Surabaya.

Lestari, Lis. 2013. Pengaruh Penyuluhan Dengan Menggunakan Metode Demonstrasi Dan Bedside Teaching Terhadap Keterampilan lbu Melakukan Pijat Bayi Di Tinjau Dari Paritas. Masters Thesis, Universitas Sebelas Maret. https://eprints.uns.ac.id/21131/.

Nugroho, C. 2013. Pengaruh Demonstrasi Pijat Bayi Terhadap Minat Ibu Untuk Melakukan Pijat Bayi Secara Mandiri. Jurnal AKP Vol.4 No.1, 26.

Riksani, Ria. 2012. Cara Mudah Dan Aman Pijat Bayi. Dunia sehat, Jakarta.
Rismundari, Devi dan Sri Sumaryani. 2012. Pengaruh Pendidikan Kesehatan Pijat Bayi terhadap Perilaku Ibu dalam Melakukan Pijat Bayi secara Mandiri di Posyandu Krikilan Ngaglik Sleman Yogyakarta. Skripsi. STIKES 'Aisyiyah Yogyakarta. http://digilib.unisayogya.ac.id/77 9/.

Subakti Y, D. R. 2008. Keajaiban Pijat Bayi \& Balita. PT Wahyu Media, Jakarta Selatan.

Yahya, N. 2011. Spa Bayi \& Anak. PT Tiga Serangkai Pustaka Mandiri, Solo.

${ }^{1}$ Dosen Akper Adi Husada Surabaya 